\title{
Velkommen til Merkolland - legitimeringsstrategier i den offentlige debat om eurokrisen
}

\author{
Sine Nørholm Just \\ Lektor, Department of Business and Politics, Copenhagen Business School
}

I den offentlige iscenesættelse og legitimering af løsningerne på eurokrisen dominerer en elitær politisk forhandlingslogik personificeret af den tyske kansler og den franske præsident, der udelukker de europæiske borgere som aktive deltagere og forfejler at indløse det solidariske og demokratiske potentiale, som ligger i den aktuelle politisering af det europæiske samarbejde. Merkolland er derfor et sjælløst sted.

\section{Indledning}

'Merkolland' er en personificering af den tysk-franske akse i europæisk politik, et udtryk for at samarbejdet mellem Angela Merkel og Francois Hollande har afløst den tidligere 'Merkozy'-relation mellem den tyske kansler og Hollandes forgænger på den franske præsidentpost. Men Merkolland er også en metafor for den reform af det europæiske projekt, som samarbejdet mellem Frankrig og Tyskland kan resultere i. Hvis det lykkes Merkel og Hollande at opnå enighed indbyrdes og at få resten af regeringslederne med sig, hvordan bliver så EU som Merkolland? Dette spørgsmål udgør omdrejningspunktet for nærværende artikel, men fokus er ikke på Merkollands indholdsmæssige eller institutionelle opbygning. I stedet er det Merkollands grundlæggende rationalitet og legitimeringsform, der er i søgelyset, og for at undersøge disse størrelser vender jeg mig mod de ansatser til konstitueringen af Merkolland, der allerede eksisterer i den offentlige debat.
Snakken om EU-reform i bred forstand udspringer af det mere konkrete - om ikke mindre udfordrende spørgsmål om, hvordan eurokrisen kan løses. Her peger vedtagelsen af først finanspagten og dernæst vækstpagten på, at Merkel og Hollande i princippet repræsenterer to forskellige lejre, stramninger versus investeringer, men at disse i praksis kan sameksistere ved simpelthen at blive lagt oven på hinanden. På samme måde indikerer den bredere reformsnak, at Hollandes ønske om en dybere økonomisk union ikke nødvendigvis står i direkte kontrast til, men derimod kan bruges som løftestang for Merkels krav om en dybere politisk union. Argumentet er, at øget økonomisk integration kræver tilsvarende politisk integration, så det overstatslige europæiske niveau tilføres både magt og legitimitet.

Som allerede antydet er denne artikels fokus ikke, hvorvidt konstitueringen af EU som Merkolland kan og vil lykkes, eller hvad den konkret vil indebære, men derimod hvordan den begrundes, hvilket legitimeringspotentiale den besidder, og hvilke konsekvenser det kan have for borgernes opfattelse af og tilslutning til EU-samarbejdet. På baggrund af de ovenfor skitserede modstillinger og tilnærmelser mellem Merkels og Hollandes positioner samt de teorier om relationen mellem offentlig meningsdannelse og EU's legitimering, der præsenteres nedenfor, har jeg opstillet tre hypoteser, som det er artiklens formål at efterprøve. Den første hypotese er, at der i den offentlige debat - og dermed i den mulige konstituering af EU som Merkolland - er fokus på økonomisk og politisk output. Det er, givet den økonomiske krise og det medfølgende behov for at udvise politisk handlekraft, forståeligt. Den 
anden hypotese er imidlertid, at det i et bredere reformperspektiv betyder, at den solidaritet mellem fremmede, som kan udspringe af et fokus på politisk input og social legitimitet, hverken italesættes som et centralt element i debatten eller aktiveres som en mulig konsekvens af den. Den tredje hypotese er, at EU som Merkolland, sådan som denne størrelse foreløbig konstitueres i den offentlige debat, forbliver et noget sjælløst sted.

For at udforske og udfordre disse tre hypoteser vil jeg i det følgende foretage en retorisk analyse af den debat om EU's fremtid, der udspringer af forsøgene på at løse eurokrisen. Nærmere bestemt fokuserer jeg på den fortælling om Merkolland, der skabes og cirkuleres i den offentlige sfære, og på de rationalitetsformer, der knytter sig til fortællingen. Med andre ord, hvordan ser Merkolland ud som retorisk konstruktion, og hvad er de mulige konsekvenser heraf? Mit fokus på Merkolland som retorisk konstruktion indebærer også et fokus på Merkel og Hollande som retoriske (og politiske) aktører. Det er naturligvis udtryk for en noget forsimplet tilgang til debatten; blandt andet ignoreres andre centrale aktører og andre mulige konstruktioner. Imidlertid kan der argumenteres for vigtigheden af at fokusere på den fransk-tyske akse, da det realpolitisk næppe er muligt at vedtage reformer, uden at Frankrig og Tyskland begge støtter op om dem, og da de to lande historisk set ikke kun har været tilhængere af, men også initiativtagere til de reformer, der er blevet til noget. Også EU's tidligere og nuværende inkarnationer kan altså ses som resultatet af et tæt samarbejde mellem statsledere fra Frankrig og Tyskland.

Forud for analysen af Merkolland som retorisk konstruktion præsenteres det teoretiske perspektiv, som mine hypoteser både udspringer af og er designet til at teste. Denne artikel er stærkt inspireret af Jürgen Habermas' teori om EU's legitimeringsproces med dens tilhørende kritik af EU's manglende legitimitet samt forslag til, hvordan legitimiteten kan styrkes. Jeg søger imidlertid via hypotesetestningen ikke blot at fælde en teoribaseret dom over EU's nuværende tilstand. I stedet håber jeg empirisk at kunne be- eller afkræfte, at EU-debatten, som den udspiller sig omkring konstruktionen af Merkolland, er domineret af instrumentel rationalitet/forhandling snarere end kommunikativ handlen/deliberation, hvilket begrænser rækkevidden af den konstitutive retorik til det systemiske niveau (hypotese et og to). Dette spørgsmål om debattens rationalitetsformer og hvem/hvad de konstituerer, er udtryk for en omskrivning af Habermas' abstrakte legitimitetsteori til analyserbare størrelser, hvilket jeg vil uddybe og begrunde som afslutning på teoriafsnittet og overgang til analysen. Endelig kan det på baggrund af analysen diskuteres, omend ikke endeligt etableres, hvorvidt der er hold i hypotese tres vurdering af
EU's fremtidige konstituering. Denne diskussion vil blive påbegyndt i artiklens afsluttende afsnit.

\section{EU's legitimeringskrise - Habermas genbesøgt}

Som optakt til gennemgangen af Habermas' teori om og normative vurdering af EU's legitimitetsproblemer er det relevant med en kort introduktion til legitimitetsbegrebets anvendelse i EU-konteksten og mere konkret til spørgsmålet om, hvorvidt der eksisterer en europæisk offentlighed, samt hvad det betyder for legitimitetsspørgsmålet. Dernæst præsenteres Habermas' særlige perspektiv på EU’s legitimitet. Her gennemgår jeg først den rolle, som offentlig meningsdannelse ifølge Habermas spiller for EU's legitimering. Og bagefter behandler jeg det, der for ham udgør løsningen på EU's nuværende problemer, nemlig etableringen af en egentlig europæisk forfatning. Som afslutning på teorigennemgangen vil jeg som nævnt operationalisere Habermas' perspektiv og dermed etablere det metodiske grundlag for den efterfølgende analyse.

\section{EU's økonomiske, politiske og sociale legitimitet}

Et politisk systems legitimitet kan overordnet bestemmes ud fra, i hvor høj grad systemet retfærdiggøres over for og accepteres af dets medlemmer (Banchoff \& Smith 1999, 4). Mere konkret kan man inddele legitimitet i en juridisk, politisk og social dimension, hvor den juridiske legitimitet knytter sig til systemets lovmæssighed, den politiske legitimitet dækker over systemets rimelighed, og den sociale legitimitet handler om, hvor accepteret systemet er (Beetham 1991, 19). Jeg vender tilbage til den juridiske dimension i forbindelse med, at jeg præsenterer Habermas' argument for en europæisk forfatning, og vil her koncentrere mig om den politiske og den sociale dimension.

Politisk legitimitet kan yderligere opdeles i en output- og en input-dimension, hvor output betegner de resultater, som systemet leverer, dets løsninger på sociale problemer (Scharpf 1999), mens input betegner graden af transparens og muligheden for deltagelse i beslutningsprocesser (Lenaerts \& Desomer 20002, 1225). Output handler i høj grad om systemets effektivitet, at der leveres mest muligt til den lavest mulige pris (Schimmelfennig 1996, 12), og kan på den baggrund også betegnes økonomisk legitimitet. Det kan måske forekomme reduktionistisk at opfatte output legitimitet som et udtryk for, hvilke $ø$ konomiske goder systemet giver sine medlemmer, men historisk er det sådan, begrebet er blevet forstået og anvendt i EU. Legitimeringen af EU via økonomisk output ligger til grund for det oprindelige fokus på økonomisk integration, hvor ideen var, at økonomisk vækst ville føre andre goder med sig - først og fremmest fred - og at dette i sig selv ville være legitimation nok (McCormick 2002, 
13). Eller sagt på en anden måde, EU's legitimitet er baseret på varetagelse af medlemmernes forskellige interesser snarere end på en underliggende forestilling om fælles identitet (Jones 2009, 1086).

Habermas argumenterede i 2001 for, at denne legitimeringsstrategi har nået sit bristepunkt:

... the rational expectation of mutual benefits within Europe and of differential competitive advantages on world markets could, to date, provide legitimation 'through outcomes' for an ever closer Union. But [...] it seems clear that henceforward economic achievements can at best stabilize the status quo (8).

Den omfattende litteratur om EU's demokratiske underskud understøtter denne pointe (se Follesdal \& Hix 2006 for en god introduktion til debatten). Her flyttes fokus fra output til input, og de forskere, der mener, at EU har et demokratisk underskud, argumenterer for, at den magt, som er nødvendig for at levere økonomiske resultater og andet output, ikke er tilstrækkeligt understøttet af borgernes evne til at påvirke EU's arbejdsgange og beslutninger (McCormick 2005, 135). Eller som Habermas formulerer det: "Economic expectations alone can hardly mobilize political support for the much riskier and farreaching project of a political union" (2001, 8).

Ud over spørgsmålet om repræsentation og deltagelse, altså om EU's politiske (input) legitimitet, bringer diskussionen om det demokratiske underskud også EU's sociale legitimitet i spil. Det helt centrale spørgsmål er her, om EU har/behøver et folk (Jolly 2005), og om et sådant folk kan skabes i og med den europæiske offentlige sfære (Risse $\&$ Van de Steeg 2003). I en nyere anmeldelse af centrale udgivelser om emnet fastslår Christian Nitoiu (2012), at hvor der i litteraturen er bred enighed om den offentlige sfæres legitimeringspotentiale, så er der stor uenighed om, hvorvidt den offentlige sfære er en myte, en realitet eller en målsætning. Altså, hvis der er en europæisk offentlig sfære med tilhørende offentlig debat, så er der også en offentlighed, dvs. en fælles europæisk bevidsthed, kollektiv identitet eller demos (kært barn har mange navne), men er der en europæisk offentlig sfære? Habermas er fortaler for opfattelsen af den europæiske offentlighed som en målsætning - eller et endnu uudnyttet potentiale, for nu at bruge et af hans egne foretrukne udtryk - og bidrager både med forklaring på, hvordan offentlig meningsdannelse og legitimering hænger sammen, og med et bud på, hvordan legitimeringspotentialet kan realiseres.

\section{Offentlig meningsdannelse og legitimeringens dynamik}

Med udgangspunkt i sin generelle teori om deliberativt demokrati argumenterer Habermas for, at EU har et særligt stort legitimitetspotentiale - netop fordi Unionen ikke har et folk. ${ }^{1}$ Argumentationen hviler på den antagelse, at kultur og politik kan og bør være adskilte størrelser. Borgernes solidaritet med hinanden og tilslutning til det politiske system bør ikke bero på en indbyrdes lighed, en fælles identitet og den dertilhørende eksklusion af de(t) fremmede (Habermas 1998, 118). Tværtimod er 'solidaritet mellem fremmede' en væsentlig legitimeringsfaktor i det deliberative demokrati; legitimitet bør hverken være identitetsbåren eller baseret på en varetagelse af særinteresser, sådan som EU's nuværende legitimering er det. I stedet skal en anerkendelse af en fælles interesse opstå af den deliberative proces, dvs. i og med offentlig meningsdannelse (Just 2005, 20-22). Habermas repræsenterer dermed det synspunkt, at EU's sociale legitimitet ikke bygger på en fælles europæisk identitet eller kultur i substantiel eller såkaldt 'tyk' forstand (Cederman 2001), men derimod kontinuerligt skabes og bekræftes via borgernes deltagelse i den offentlige meningsdannelse. Social legitimitet er ikke en statisk størrelse, der er forankret i en enhedskultur, men derimod en dynamisk proces, der udspringer af en levende og inklusiv offentlig debat - af borgernes input til det deliberative demokrati.

Når Habermas etablerer offentlig meningsdannelse som den centrale legitimeringsproces for det deliberative demokrati, trækker han både på sine teorier om den offentlige sfære og den kommunikative handlen. To forhold er særligt vigtige: for det første skelner Habermas mellem livsverdenen på den ene side og systemet på den anden (Habermas 1996a), hvilket i teorien om den offentlige sfære præsenteres som et skel mellem offentligheden og staten (Habermas 1989, 30). I begge teorier er pointen, at systemet/staten med sin instrumentelle rationalitet ikke kan legitimere sig selv, men i stedet må hente sin legitimitet i livsverdenen/den offentlige sfære, hvor meningsdannelse finder sted via det bedre arguments såkaldt 'besynderligt tvangfrie tvang' (Habermas 1993, 163). Forskellige faktorer besværliggør imidlertid denne legitimeringsproces, og der er tendenser til, at systemet koloniserer livsverdenen/den offentlige sfære refeudaliseres. ${ }^{2}$ For det andet opstiller Habermas normer for, hvordan den gode offentlige debat, der kan legitimere systemet og afværge de negative tendenser, bør foregå. Dette sker dels som et sæt betingelser for den offentlige sfæres hensigtsmæssige indretning, dels som et sæt normer for den kommunikative handlen. Habermas har godt nok redefineret offentligheden som et dynamisk netværk snarere end en statisk sfære (1996b, 360) og pointeret, at beskrivelsen af den borgerlige offentlighed er en webersk idealtype, sna- 
rere end et normativt ideal, men han anerkender samtidig den oprindelige teoris normative undertoner (1992, 442). Med disse forbehold kan der opstilles fire betingelser for den velfungerende offentlige sfære: den skal som allerede nævnt være adskilt fra staten, den skal udgøre et hele, snarere end bestå af adskilte deloffentligheder, sociale uligheder skal sættes i parentes, og der skal argumenteres ud fra det fælles bedste i stedet for særinteresser (Fraser 1992, 117f). Man kan se dette første sæt af normer som de brede rammer, der muliggør udøvelsen af en debat, som lever op til normerne for kommunikativ handlen. Disse normer tilsiger, at alle bidrag til debatten skal kunne efterprøves med hensyn til deres sandhed, rigtighed og sandfærdighed; altså, ud fra hvordan de forholder sig til en objektiv virkelighed, en social kontekst og en subjektiv erfaring (Habermas 1996a, 262).

I forhold til spørgsmålet om EU's legitimitet er Habermas som nævnt fortaler for, at den europæiske offentlighed opfattes som en målsætning eller et potentiale. Pointen er, at der endnu ikke findes en europæisk offentlig sfære/offentlig debat, som lever op til normerne for den meningsdannelsesproces, der kan levere input legitimitet til EU-systemet, men at der i princippet ikke er noget til hinder for, at den kan opstå. Habermas afviser, at manglen på fælles medier, fælles sprog og fælles identitet i sig selv umuliggør legitimerende offentlig meningsdannelse, og hævder i stedet, at der godt på det nuværende grundlag kan skabes en europæisk offentlighed, der kan danne udgangspunkt for EU's legitimering (2001, 18).

\section{Behovet for en europeisk forfatning}

Det er på dette sted i argumentationen, at spørgsmålet om juridisk legitimitet melder sig på banen igen. Habermas mener nemlig, at det, EU har brug for, er en forfatning. Det var hans bud på en løsning af EU's legitimitetsproblemer for ti år siden (Habermas 2001), og han mener fortsat, at det er vejen frem. Faktisk argumenterer han for, at EU i den nuværende krisesituation har mere behov for en forfatning end nogensinde før (Habermas 2012).

Argumentet er tosidet; på den ene side er det tanken, at en fælles accept af de regler, procedurer og institutioner, der opstilles i forfatningen, kan træde i stedet for det substansbaserede fællesskab. Habermas kalder denne form for fællesskabsfølelse for forfatningspatriotisme og mener, at den rummer alle patriotismens positive elementer, samtidig med at de mørke nationalistiske tendenser undgås (Nanz 2001, 36). Forfatningen som produkt vil altså være legitimt og legitimerende. På den anden side er det selve den forfatningsgivende proces, der skal blive genstand for og udløser af den fælleseuropæiske offentlige debat, som i øjeblikket er fraværende (Habermas 2009, 58).
I Habermas' optik kan og bør det europæiske folk så at sige konstituere sig selv, hvilket ikke bare er en teoretisk pointe, men også var et væsentligt rationale bag den forfatningsproces, som EU's stats- og regeringsledere igangsatte i 2001. Her var tanken, at et politisk forum, det såkaldte konvent, skulle agere samlingspunkt og generator for en bred offentlig debat, der kunne udløse et konstituerende øjeblik (jf. Laeken-erklæringen 2001). Det vil sige en situation, hvor EU ikke bare ville få en ny traktat/forfatning, men hvor borgerne også ville tilslutte sig denne; hvor der blev etableret forfatningspatriotisme på EU-niveau. Forløbet fra $2001 \mathrm{og}$ frem til vedtagelsen af Lissabon-traktaten i 2009 viser med al ønskelig tydelighed, at her nok var tale om en forfatningsproces, men at det konstituerende øjeblik udeblev. Processen førte dermed hverken til, at EU fik et grundlæggende dokument, der åbent kalder sig selv en forfatning, eller til at EU's borgere fandt sammen i et fællesskab, der ikke er baseret på substantielle ligheder, men i stedet på formelle regler. I 2001 formulerede Habermas problematikken og dens potentielle løsning således:

\section{The economic advantages of European unification are valid as arguments for further construction of the EU only if they can appeal to a cultural power of attraction extending far beyond material gains alone. Threats to this form of life [velfærdsstaten], and the desire to preserve it, are spurs to a vision of Europe capable of responding inventively to current challenges (9).}

Dengang var sporerne åbenbart ikke skarpe nok; spørgsmålet er, om de er det i dag. Kan eurokrisen udløse et konstituerende øjeblik?

\section{Fra legitimeringsstrategier til rationalitetsformer}

Selvom det habermasianske udgangspunkt medfører en afvisning af, at kollektiv identitet og social legitimitet beror på indholdsmæssige ligheder, er der alligevel, som det ovenstånde citat indikerer, tale om en form for kulturelt fællesskab. Et fællesskab, der opstår refleksivt som resultat af fælles meningsdannelsesprocesser i stedet for at bero på en forudgående antagelse om fællesskabets eksistens (Habermas 1997, 264). Det afgørende bliver her eksistensen og kvaliteten af disse meningsdannelsesprocesser; altså, er der (ved at opstå) en europæisk offentlig sfære, og hvis ja, hvilken form for offentlig debat er den så befordrende for?

Jeg vil i det følgende se bort fra spørgsmålet om, hvorvidt den europæiske offentlige sfære eksisterer som en rumlig og/eller statisk konstruktion, og i stedet følge 
Habermas' seneste definition af den offentlige sfære som et netværk samt hans pointe om, at fælles processer ikke nødvendigvis kræver fælles medier. Habermas argumenterer for, at vi skal gå bort fra at tænke på den europæiske offentlighed som en overnational størrelse og i stedet behandle den fra et transnationalt perspektiv som '... an interpenetration of mutually translated national communications' (2001, 18). Forholder man sig til den offentlige debat om eurokrisen ud fra dette perspektiv, kan man umiddelbart svare ja til, at det samme emne diskuteres i de forskellige (nationale) offentligheder, og at man inden for disse ikke blot er opmærksom på sin egen debat, men også på de bidrag til debatten, der udgår fra andre offentligheder. Nok bliver vi ikke i Danmark informeret om hver enkelt drejning i debatten i hvert af de andre EU-lande, men der er i Danmark - og de øvrige offentligheder - en forståelse for og en opmærksomhed på de væsentligste aktører og de vigtigste begivenheder. Samtidig kan man faktisk argumentere for, at der i og med den engelsksprogede og internetbaserede mediedækning af eurokrisen (og måske endda EU som sådan) er opstået et overnationalt rum for europæisk debat; dette rum understøttes af europæiske medier som fx euobserver.com og euractiv.com, medier med baggrund i en engelsksproget national kontekst som $\mathrm{fx}$ ft.com og guardian.co.uk og af medier, der udspringer af en anden sproglig kontekst, men nu også udkommer på engelsk online, fx spiegel.de/ international og http://mondediplo.com, ligesom blogs og sociale medier er med til at skabe mulighed for overnationale meningsdannelsesprocesser.

Det er med udgangspunkt i disse observationer, at jeg i det følgende fokuserer på, hvordan Merkolland konstrueres i de(n) europæiske offentlighed(er). Som nævnt er Merkel og Hollande langt fra de eneste centrale aktører, og der er både andre aktører, der går igen i hver kontekst ( $\mathrm{fx}$ Van Rompuy og Barroso), ligesom den enkelte kontekst vil have sine egne særlige aktører ( $\mathrm{fx}$ nationale parlamentarikere). På samme måde er fortællingen om Merkolland ikke den eneste mulige udlægning af, hvordan EU kan komme ud af krisen, men det er en central fortælling, og studiet af den kan give en indikation på debattens beskaffenhed. Formålet med analysen bliver dermed at vurdere kvaliteten af den offentlige debat, og dette sker ud fra, men også som et kritisk empirisk blik på, Habermas' normer for deliberativt demokrati.

For at teste, om debatten kan forstås som en meningsdannelsesproces, der har potentiale til at forlene det politiske system med konkret input og bredere social legitimitet (hvor det sidste her skal forstås i Habermas' tynde forstand som solidaritet mellem fremmede), er det imidlertid nødvendigt at konkretisere og operationalisere normerne for den kommunikative handlen. Til det formål benytter jeg mig af to analytiske greb. For det første Jon Elsters skel mellem instrumentel forhandling og konsensusskabende deliberation (Elster 1991, Elster (red.) 1998; se også Just 2007). Elster definerer deliberation som den kommunikationsproces, der har til formål at overbevise modstanderen og altså har enighed som sit mål, mens forhandling sigter imod at tvinge eller lokke modstanderen til at acceptere det synspunkt, man selv forfægter (Elster 1991, 1-2). Spørgsmålet bliver altså, om fortællingen om Merkolland har fælles meningsdannelse som sit mål, eller om den handler om, hvordan modstridende positioner kæmper mod hinanden. For yderligere at belyse dette spørgsmål og for at undersøge, om og hvordan borgerne inddrages i et (tyndt) solidarisk fællesskab, benytter jeg Maurice Charlands begreb om konstitutiv retorik $(1987,2001)$. Charland definerer konstitutiv retorik som en genre, der “... simultaneously presumes and asserts a fundamental collective identity for its audience, offers a narrative that demonstrates that identity, and issues a call to act to affirm that identity" (2001, 616). Altså, er der i fortællingen om Merkolland en antagelse om og en demonstration af en kollektiv identitet, der peger på et særligt handlingspotentiale, og hvem/hvad er det i så fald, der konstitueres som handlende kollektiv.

\section{Merkolland som retorisk konstruktion}

I forsøget på at teste mine hypoteser om, hvordan Merkolland konstitueres, vil jeg i det følgende først opstille fortællingen om Merkolland, som den kan udledes af den engelsksprogede og netbaserede mediedækning af samarbejdet mellem Merkel og Hollande, samt dette samarbejdes (mulige) konsekvenser for løsningen af eurokrisen i særdeleshed og EU's reformproces i almindelighed. Samtidig vil jeg afdække, hvilke rationalitetsformer fortællingen er styret af, og på baggrund af denne første analyserunde vil jeg diskutere Merkollands identitet og legitimitet og dermed besvare spørgsmålet om, hvorvidt og hvordan EU konstitueres som Merkolland.

Inden jeg går i gang, er det imidlertid nødvendigt med et sidste forbehold: ligesom enhver anden fortælling (Bakhtin 1986, 91) er historien om Merkolland indspundet $\mathrm{i}$ andre historier, $\mathrm{fx}$ historien om eurokrisen, historien om det fransk-tyske samarbejde og EU's generelle udviklingshistorie. Det vil sige, at fortællingen egentlig begynder, længe inden den konkrete samarbejdsrelation mellem Merkel og Hollande opstod, og at den vil fortsætte, efter at de to har forladt den politiske scene (jf. Burke 1941, 110-111). Det følgende skal altså ikke bare ses som en beskrivelse af et hændelsesforløb, men også som en analytisk konstruktion (Gulbrandsen \& Just 2011). I og med at jeg rekonstruerer historien om Merkolland, bliver jeg uvægerligt også medskaber af den. 


\section{Fortallingen om Merkolland}

Det udsnit af historien, jeg beskæftiger mig med, tager sin begyndelse den 15. maj 2012, men det er vigtigt at medtage den korte forhistorie, som er den, at Merkel under den franske præsidentvalgkamp havde støttet Nicolas Sarkozy, med hvem hun formede det stærke 'Merkozy'partnerskab, mens Hollande havde været stærkt kritisk over for dette partnerskab og den finanspagt, som i høj grad var et resultatet af det (Traynor 06/05/12). Umiddelbart efter at Francois Hollande var blevet valgt som fransk præsident, blev den antagonistiske retorik imidlertid lagt på hylden. Merkel var blandt de første til at lykønske Hollande, og denne kvitterede med at række hånden ud til et nyt fransk-tysk samarbejde (AFP 07/05/12). Det fik flere kommentatorer til at mene, at Merkel og Hollande nu ville finde sammen i et fornuftsægteskab:

\section{It is probable that Merkel and Hollande will melt into „Merkollande“ after a few months of getting a sense for one another. But it will represent a marriage of convenience more than anything else. The conservative chan- cellor will perhaps be drawn to Francois Hollande's quieter personality - in contrast to Nicolas Sarkozy's impulsiveness. France and Germany will remain the motors driving the EU even though there may be some sputte- ring at first (Riegert 07/05/12).}

Denne prognose blev umiddelbart bekræftet den 15. maj, da Hollande, straks efter at han var blevet taget i ed som fransk præsident, trodsede vejr, vind og lynnedslag i det præsidentielle fly for at aflægge Merkel et besøg i Berlin (France24 16/05/12).

Under besøget den 15. maj blev grundstenen til Merkolland-samarbejdet lagt; den hedder 'både-og'. Hvor Merkel tidligere havde talt for økonomiske stramninger og mod offentlige investeringer, mens Hollande havde forfægtet det modsatte synspunkt, blev de to tiltag nu præsenteret som supplement til hinanden (France24 16/05/12). Det vil sige, at Hollande ikke længere snakkede om, at finanspagten skulle genforhandles, men i stedet argumenterede for at føje en vækstpagt til den eksisterende aftale, og at Merkel støttede op om denne model.

Både-og-strategien muliggør et samarbejde mellem Merkel og Hollande, men gør ikke samarbejdet gnidningsfrit. Især står Hollandes ønske om at indføre euroobligationer i kontrast til Merkels udtalelser om, at det ikke kommer til at ske i hendes levetid (EurActiv 27/06/12). Her får Hollande opbakning fra en række af de andre eurolande, der også ønsker øget økonomisk integration, og der har tegnet sig et billede af, at Merkel står mere og mere alene med sin stramningspolitik (cro 21/05/12). Merkollands historie kan derfor til en vis grad ses som historien om, hvor langt Hollande kan presse Merkel ned ad vækstvejen, men igen er der blevet etableret et muligt 'både-og'-alternativ til denne taber-vinder-fortælling. På Merkels initiativ skal politisk integration nemlig lægges oven på økonomisk integration. Eller med hendes egne ord: „Control and liability have to go hand in hand and joint liability can only happen when sufficient controls are in place" (RTÉ News, 28/06/12). Dette er ikke Hollandes ønskescenarie, men et han har accepteret for at få vækstpagten igennem. Eller som han har udtrykt det: „We both want to deepen economic, monetary - and in the future political - union, to arrive at integration and solidarity" (RTÉ News, 28/06/12). Dette er udgangspunktet for 'det store kompromis', som Merkolland-samarbejdet ofte betegnes som: politisk union i bytte for økonomisk solidaritet (McBride 10/07/12). På det generelle plan er Merkels og Hollandes positioner altså forenelige, men djævlen er i detaljen, for hvad kommer først: politisk eller økonomisk integration, og hvor hurtigt skal hvad ske?

I maj-juni var enigheden - og støtten til Hollande fra andre EU-lande - stærk nok til, at vækstpagten med dens løfte om en bankunion kunne vedtages ved Rådsmødet i slutningen af juni (Velón 06/07/12). Efterfølgende nåede Merkolland et symbolsk højdepunkt, da de to statsledere i juli og september sammen fejrede 50 -året for den fransktyske forsoning. ${ }^{3}$ Her fremhævede de begge eksistensen af et fransk-tysk - og europæisk - fællesskab:

\section{"The only response to the crisis is Europe, it is Europe that will beat the crisis," he [Hol- lande] said, concluding in German: „Long live Franco-German friendship!" Merkel finished her own speech with a line in French: „Long live Franco-German youth, long live European youth!“ (Saltz 22/09/12).}

Forud for topmødet i oktober brød uenigheden om, hvordan og hvornår de konkrete reformer skal gennemføres, imidlertid for alvor ud igen. Hollande talte om en hurtig realisering af bankunionen, mens tidsperspektivet for Merkel var længere, og hun fokuserede på oprettelsen af en budgetunion (EUbusiness 18/10/12). The Guardian udlagde situationen således: "Hollande's key aim was to speed up the establishment of the new banking regime, while Merkel emphasised 'quality over speed' as part of her delaying tactics" (Traynor 19/10/12). Selvom mødet resulterede i et konkret kompromis om at etablere et banktilsyn (Volkery 19/10/12), blev der ikke i denne runde etableret nogen både-og-model. Eller som Spiegel Online formulerede det: 


\section{Europe's most powerful political team is unable to find a common denominator, from the question of who should be picking up prizes or, more tellingly, to the much broader issue of rescuing the euro. At the Brussels summit last week, Merkel and Hollande, after arguing for hours, agreed on a slim formulaic compromise on the banking union, while all other contentious issues remained unresol- ved (Spiegel Staff 22/10/12).}

På den baggrund var forventningerne til topmødet i december ikke de mest optimistiske; godt nok havde man i oktober besluttet at træffe en beslutning i december, men den fortsatte uenighed skabte tvivl om, hvorvidt denne udsættelsesstrategi ville bære frugt. Som en kommentator fastslog forud for decembermødet: „This week's summit is likely to combine the worst of two worlds: meager results with a lot of quarreling" (Hasselbach 13/12/12). At der faktisk i december blev indgået en aftale om det fælles banktilsyn og vejen frem mod dets implementering $\mathrm{i}$ marts 2014, kan i det lys ses som en stor sejr, måske endda en historisk bedrift. Imidlertid er det lige så sigende for den drejning, som fortællingen om Merkolland nu har taget, at aftalen i højere grad blev præsenteret som en teknokratisk løsning end en politisk reform. Den udvidelse af reformprocessen fra en løsning af eurokrisen til en rekonstituering af EU, som var under optræk i majjuni, synes i oktober-december at være stagneret, hvis ikke ligefrem rullet tilbage.

Historien om Merkolland, som den har udspundet sig fra maj til december 2012, er altså historien om tøvende tilnærmelser og kontante konflikter. I tiden mellem topmøder har der typisk været fokus på, hvordan Merkel og Hollande nærmer sig hinanden og arbejder på at afstemme deres synspunkter, under og lige efter topmøderne har den dominerende vinkel været, at og hvordan de sætter hårdt mod hårdt. Sammenstødet resulterede i juni i en aftale om vækstpagten, hvilket i medierne blev udlagt som en sejr til Hollande. Oktobermødets manglende resultater blev derimod fortolket som, at Merkel løb af med sejren, da den økonomiske integration dermed forsinkedes, hvilket kunne øge muligheden for, at den politiske integration kobles direkte på yderligere økonomiske tiltag - og måske endda bliver en forudsætning for disse. Imidlertid viste oktobermødet også, hvor dybe spændingerne i samarbejdet er. Der blev talt om en tillidskrise mellem Merkel og Hollande (Spiegel Staff 22/10/12) og om, at de direkte modarbejder hinanden:
It almost seems as though Paris and Berlin are intentionally getting in each other's way. Germany wants to further stiffen EU budgetary rules and would like to amend EU treaties as quickly as possible next year to make it possible. France, on the other hand, believes the priority should be the collectivization of debt and rapidly installing bank oversight. For the summit, the result is likely to be a stalemate. The new Franco-German partnership of Merkollande is on the verge of earning a less flattering moniker: Merde (Volkery 18/10/12).

Selvom det fælleseuropæiske banktilsyn blev vedtaget ved decembermødet, blev dette hverken udlagt som en entydig tilnærmelse mellem Merkel og Hollande eller som en klar sejr til en af dem. I stedet synes fortællingen om Merkolland i øjeblikket at miste momentum, idet Merkel og Hollande i stigende grad fokuserer på nationale problemstillinger (hhv. det kommende tyske valg og den skrantende franske økonomi), samtidig med at presset for yderligere EU-reformer er aftagende (pga. indikationerne på, at de nu vedtagne tiltag har en vis effekt). Det udsnit af historien, som jeg har præsenteret her, slutter altså med noget af en cliffhanger: hvorvidt Merkel og Hollande igen kan finde fælles fodslag om den reformproces, der kan konstituere EU som Merkolland, vil afhænge både af, hvordan de to håndterer deres respektive nationale situationer, og af, hvorvidt de kriseramte eurolande fortsætter den bedring, de tilsyneladende er inde i. Altså, hvor presserende vil det fortsatte behov for økonomiske og politiske reformer vise sig at være, og hvor stor vilje og magt vil Merkel og Hollande have til at gennemføre dem?

\section{Merkollands rationalitetsformer og legitimering}

Fortællingen om Merkolland, som jeg har rekonstrueret den i forrige afsnit, er først og fremmest styret af forhandlingens noget-for-noget-rationalitet. Der er ikke mange tegn på, at Merkel og Hollande faktisk søger at overbevise hinanden - og at overbevise offentligheden - om deres fælles position. I stedet udlægges resultater typisk som sejre til den ene eller den anden, eller som udtryk for at begge fik noget 'med hjem'. Dermed er der ikke nogen stærk argumentation for Merkolland som helhed; etableringen af samarbejdet - det fransk-tyske og det europæiske - som både stramninger og vækst, både politisk og økonomisk integration forbliver et kompromis, hvor begge parter (og de øvrige EU-lande for den sags skyld) må acceptere noget for at få noget, men ingen argumenterer helhjertet for en samlet løsning. 
Det er dog ikke det samme som, at der ikke delibereres i den offentlige debat. Både Merkel og Hollande argumenterer for deres positioner og søger at overbevise tilhørerne, når de udtaler sig på egen hånd ( $f x$ i taler til deres respektive nationale parlamenter), men her er det netop de modstillede positioner, der understøttes: økonomiske stramninger og politisk union på den ene side og offentlige investeringer og økonomisk union på den anden. Som nævnt er der mellem topmøder tegn på, at Merkel og Hollande forsøger at nå til enighed, ligesom de også i nogen grad gør sig til fortalere for allerede opnåede kompromisser ( $\mathrm{f} x$ når der skal hentes national opbakning til dem): her erstattes enten-eller med både-og, men bliver ikke til en ny enhed. Samtidig er der ved festlige lejligheder symbolske markeringer af fællesskabet, som forlener det med en vis følelsesmæssig appel og kunne indikere, at det er andet og mere end et fornuftsægteskab - på det individuelle og det kollektive plan. Så snart der faktisk kan træffes beslutninger, er forhandlingen imidlertid den absolut dominerende rationalitetsform; i hvert fald i den version af træfningerne, som cirkulerer i det offentlige rum. Dermed er der ingen konsekvent og vedvarende deliberation for det samlede billede, ingen der tager ansvar for at konstituere Merkolland som en helhed.

Det har betydning for, hvordan fortællingen om Merkolland fungerer som konstitutiv retorik. På sæt og vis antages og etableres et kollektivt subjekt; 'vi' kom ind i krisen sammen og skal også ud af den sammen. Men forestillingen om det europæiske fællesskab forankres ikke i en fælles historie eller i en samlet opfordring til handling; der opbygges ikke et kollektiv, hvorfra der kan hentes social legitimitet. Tværtimod peger fortællingen i højere grad på fællesskabets begrænsninger end på dets sammenhængskraft, og der er intet samlet handlingspotentiale; i stedet for en konsensus om, hvem vi er, en konstituering i bredere forstand, skabes konkrete kompromisser om, hvad 'vi' skal gøre for at komme ud af krisen. Og hvad værre er: hvor det kollektive subjekt i princippet inkluderer alle EU's borgere, så er det etablerede handlerum - uanset hvor flygtigt og tyndt det er - begrænset til det politiske niveau. I fortællingen om Merkolland optræder borgerne ikke som aktører; de inkluderes ikke i det udsnit af den offentlige meningsdannelse, som jeg har studeret her, men må i stedet som tilskuere se til, at politikerne dels kæmper om forskellige løsningsmuligheder, dels implementerer de kompromisser, der bliver indgået. Dermed forbliver legitimeringen af EU som Merkolland systemisk; i bedste fald neutral i forhold til borgernes meningsdannelse, i værste fald invaderende og invaliderende i forhold til den livsverden, som kunne bidrage til ny- og genskabelsen af et legitimt politisk projekt.

\section{Solidaritet mellem fremmede som moddiskurs?}

I det omfang man overhovedet kan tale om, at Merkolland konstitueres som et handledygtigt fællesskab, er dette fællesskab baseret på forhandlingsrationalitet og systemisk legitimitet; Merkel, Hollande og de øvrige statsledere når (sommetider) til kompromisser om tekniske løsninger, ikke til enighed om grundlæggende principper. Det betyder, at EU, når og hvis samarbejdet konstitueres som den størrelse, jeg her har betegnet Merkolland fortsat vil være afhængigt af at levere resultater til borgerne som interessenter. Fortællingen om Merkolland, involverer ikke borgerne aktivt - hverken via deliberation møntet på at overbevise dem om reformernes rigtighed i andet end teknisk forstand eller ved direkte at invitere dem til at deltage i debatten. Og når borgerne positioneres som passive modtagere af EU's resultater, etableres der ikke i og med den offentlige meningsdannelse en solidaritet mellem fremmede, som muliggør, at de kan forholde sig til og acceptere løsninger, der ikke direkte kommer dem selv til gode. Min opstilling og analyse af fortællingen om Merkolland bekræfter altså de to første hypoteser: der er fokus på output legitimitet på bekostning af input og social legitimitet. Jeg må dog her indskyde et metodekritisk forbehold; givet at jeg som nævnt er medskaber af fortællingen, er der en vis risiko for, at jeg har konstrueret den, så den passer til mine antagelser. Derfor må der tages højde for, at dette er én, men ikke nødvendigvis den eneste tendens i den offentlige debat.

Netop derfor er det vigtigt at diskutere hypotese tre i stedet for at antage, at Merkolland nødvendigvis er sjælløst, fordi fortællingen, som jeg har præsenteret den, er det. Eller med andre ord: kan og vil en meningsdannelsesproces, der har solidaritet mellem fremmede som sit fokus og sit mål, opstå andetsteds? Ikke (nødvendigvis) som et resultat af den officielle version af Merkolland, men som et alternativ, måske en direkte modsætning, til den? Vi får en første indikation på, at dette er en reel mulighed, ved at vende blikket fra de internetbaserede nyhedsmedier til de sociale medier og fra topmøder og forhandlingslokaler til folkelige protester på gadeplan. Her bliver det klart, at borgerne ikke er tilfredse med at se passivt til, mens politikerne løser problemerne, men tværtimod kræver at blive set, hørt og taget alvorligt. De folkelige protestbevægelser er godt nok nationalt forankrede i deres fysiske manifestationer og i visse tilfælde også baseret på EU-skepsis og/eller nationalisme, men flere af dem rummer ansatser til europæisk momentum via sociale netværk (og via samtidige og koordinerede protester). Her findes et uudnyttet potentiale for social legitimering - hvis det kan lykkes at række hen over den kløft mellem politikerne og befolkningerne, som i øjeblikket synes at blive stadigt større. Dette vil imidlertid kræve andet og mere end, at 
Merkel og andre politikere udtrykker deres medfølelse med demonstranterne (jf. Merkels besøg i Grækenland og Portugal i oktober/november). Borgernes argumenter og synspunkter må også inddrages i den politiske debat og danne grundlag for de politiske beslutninger i stedet for blot at blive set som den forståelige følelsesmæssige reaktion på hårde, men nødvendige rationelle reformer.

De folkelige protestbevægelser er ikke bare udtryk for vrede mod de politiske reformer, selvom der er masser af vrede at spore - ikke bare i de nationalistiske og EU-skeptiske versioner af protesterne, men også i dem, der anerkender det europæiske skæbnefællesskab. Protesterne peger også på, at mange borgere er enige i, at 'vi' kun kan komme ud af krisen sammen; de er bare ikke indforståede med den vej ud af krisen, der vil føre til en konstituering af EU som Merkolland. Det vil altså sige, at krisen i princippet rummer et potentiale for, at en legitimerende meningsdannelsesproces kan igangsættes, men det kræver, at der skabes sammenhæng mellem politikernes fokus på at skabe resultater via reformer og borgernes krav om solidaritet. Hermed er vi tilbage ved Habermas' pointe om, at EU har brug for et egentligt forfatningsprojekt, hvor borgerne inddrages i processen, således at de også kan se sig selv i og tilslutte sig resultatet. Der er naturligvis ingen garanti for, at et sådant projekt faktisk kan lykkes denne gang, og sporene fra den sidste reformrunde skræmmer forståeligt nok de politiske ledere. Men der er en afgørende forskel mellem situationen i 2001 og nu: borgerne er allerede engagerede. Derfor handler det i denne omgang ikke om at etablere en debat, men i stedet om at sammenkoble den politiske og den folkelige meningsdannelse.

\section{Noter}

1. Dette sker i direkte opposition til Dieter Grimms argument om, at EU har brug for et folk, altså en fælles identitet, før integrationsprocessen kan fortsætte (Grimm 1997). For en gennemgang af den såkaldte 'no demos'-debat se Jolly (2005).

2. Det ligger uden for rammerne af denne artikel at redegøre for de forhold og processer, der ifølge Habermas er årsag til kolonisering/ refeudalisering, men igen er der sammenhæng mellem de to teorier; flere og flere sociale forhold reguleres via systemiske mekanismer, samtidig med at borgerne reduceres til passive tilskuere (se fx Just \& Burø 2010, 244-262 for en mere detaljeret introduktion til argumentet).

3. Et tilsvarende højdepunkt blev nået for det europæiske samarbejde som helhed, da det den 12. oktober 2012 blev offentliggjort, at EU var blevet tildelt Nobels Fredspris 2012 for sin rolle i omdannelsen af Europa fra et krigens til et fredens kontinent.

\section{Referencer}

AFP 07/05/12, 'France Election: Angela Merkel Congratulates Francois Hollande', The Telegraph, http://www.telegraph.co.uk/news/worldnews/francois-hollande/9250040/France-election-Angela-Merkelcongratulates-Francois-Hollande.html.

Bakhtin, M M 1986, Speech Genres and Other Late Essays. University of Texas Press, Austin.

Banchoff, T \& M P Smith (red.) 1999, Legitimacy and the European Union. The Contested Polity, Routledge, London.

Beetham, D 1991, The Legitimation of Power, Macmillan, London.

Burke, K 1973 [1941], The Philosophy of Literary Form: Studies in Symbolic Action, 3. edn., University of California Press, Berkeley.

Cederman, L-E 2001, 'Nationalism and Bounded Integration: What it Would Take to Construct a European Demos, International Relations, vol. 7, no. 2, pp. 139-174.

Charland, M 2001, 'Constitutive Rhetoric', in T O Sloane (red.), Encyclopedia of Rhetoric, Oxford University Press, Oxford.

Charland, M 1987, 'Constitutive Rhetoric: The Case of the Peuple Québécois', The Quarterly Journal of Speech, vol. 73, no. 2, pp. 133-150.

cro 21/05/12, 'Hollande to Confront Merkel on Euro Bonds', Spiegel Online, http://www.spiegel.de/international/europe/frenchpresident-fran-ois-hollande-to-call-for-euro-bonds-at-eu-summit-a-834180.html.

EurActiv 27/06/12, 'Merkel on Eurobonds: 'Not in my Lifetime", EurActiv, http://www.euractiv.com/euro-finance/merkel-eurobonds-lifetime-news-513581.

EUbusiness 18/10/12, 'Merkel, Hollande Differ Sharply at EU Summit', EUbusiness, http://www.eubusiness.com/news-eu/summitfinance-debt.k4y.

Elster, J 1991, Arguing and bargaining in the Federal Convention and the Assemblée Constituante, University of Chicago, Chicago.

Elster, J (red.) 1998, Deliberative Democracy, CambridgeUniversity Press, Cambridge, UK.

Follesdal, A \& S Hix 2006, 'Why There is a Democratic Deficit in the EU: A Response to Majone and Moravcsik', Journal of Common Market Studies, vol. 44, no. 3, pp. 533-562.

France 24 16/05/12, Hollande and Merkel Vow to Seek Growth for Europe, France24, http://www.france24.com/en/20120515-hollande-president-berlin-france-merkel-eurozone-inauguration.

Fraser, N 1992, 'Rethinking the Public Sphere: A Contribution to the Critique of Actually Existing Democracy', in C Calhoun (red.): Habermas and the Public Sphere, The MIT Press, Cambridge, Mass.

Grimm, D 1997 [1995] 'Does Europe need a Constitution?', in P Gowan \& P Anderson (red.), The Question of Europe, Verso, London.

Gulbrandsen, I T \& S N Just 2011, 'The Collaborative Paradigm - Towards a theory of online communication', Media, Culture \& Society, vol. 33, no. 7, pp. 1095-1108.

Habermas, J 2012, The Crisis of the European Union, Polity Press, Cambridge, UK.

Habermas, J 2009, Europe. The Faltering Project, Polity Press, Cambridge, UK.

Habermas, J 2001, 'Why Europe Needs a Constitution', New Left Review, vol. 11, Sep.-Oct, pp. 5-26.

Habermas, J 1998, The Inclusion of the Other. Studies in Political Theory, The MIT Press, Cambridge, Mass.

Habermas, J 1997 [1995]: Reply to Grimm', in P Gowan \& P Anderson (red.), The Question of Europe, Verso, London.

Habermas, J 1996a [1981], Teorien om den kommunikative handlen, Aalborg Universitetsforlag, Aalborg. 
Habermas, J 1996b [1992], Between Facts and Norms. Contributions to a Discourse Theory of Law and Democracy, Polity Press, Cambridge, UK.

Habermas, J 1993 [1983], Moral Consciousness and Communicative Action, The MIT Press, Cambridge, Mass.

Habermas, J 1992, 'Further Reflections on the Public Sphere', in C Calhoun (red.), Habermas and the Public Sphere, The MIT Press, Cambridge, Mass.

Habermas, J 1989 [1962], The Structural Transformation of the Public Sphere, Polity Press, Cambridge, UK.

Hasselbach, C 13/12/12, 'Low Expectations as EU Summit Begins', Deutsche Welle, http://www.dw.de/low-expectations-as-eu-summitbegins/a-16450016.

Jolly, M 2005, 'A Demos for the European Union?', Politics, vol. 25, no. 1 , pp. $12-18$

Jones, E 2009, 'Output Legitimacy and the Global Financial Crisis: Perceptions Matter', Journal of Common Market Studies, vol. 47, no. 5, pp. 1085-1105.

Just SN \& T Burø 2010, Kultur-og kommunikationsteori. En Introduktion, Hans Reitzels Forlag, København.

Just, SN 2007, 'Deliberative Processes and Bargained Positions. The Public (Re)presentation of the European Convention', Critical Discourse Studies, vol. 4, no. 3, pp. 257-282.

Just, SN 2005, 'Indirekte kommunikativ konstituering. Mod en forstålse af det europæiske samarbejde', Rhetorica Scandinavica, no. 35 , pp. 17-31.

'Laeken-erklæringen om den Europæiske Unions fremtid', http://www. euo.dk/upload/application/pdf/ae714352/laeken.pdf.

Lenaerts, K \& M Desomer 2002, 'New Models of Constitution-Making in Europe: The Quest for Legitimacy', Common Market Law Review, vol. 39, pp. 1217-1253.

McCormick, J 2005, Understanding the European Union, 3. edn., Palgrave, Houndsmill.

McBride, J 10/07/12, 'Insight: Merkel and Hollande - Building a 'Grand Bargain", Reuters, http://www.reuters.com/article/2012/07/10/usinsight-merkollande-idUSBRE8690K120120710.

McCormick, J 2002, Understanding the European Union, 2. edn., Palgrave, Houndsmill.

Nanz, P 2001, Europolis. Constitutional Patriotism beyond the Nation State, The European University Institute, Florence.
Nitoiu, C. (2012), 'The European Public Sphere: Myth, Reality or Aspiration?', Political Studies Review, vol. 10.

Riegert, B 07/05/12, 'Opinion: 'Merkollande' for Europe, Deutsche Welle, http://www.dw.de/opinion-merkollande-for-europe/a-15933080.

Risse, T \& M Van de Steeg 2003, 'An Emerging European Public Sphere? Empirical Evidence and Theoretical Clarifications', paper præsenteret ved konferencen Europeanisation of Public Spheres, Political Mobilisation, Public Communication and the European Union, Science Center Berlin, 20.-22. juni.

RTÉ News 28/06/12, 'Eurzone Should 'Deepen' Integration', RTÉ News, http://www.rte.ie/news/2012/0627/spain-cant-finance-itselffor-long-at-high-rates.html.

Saltz J 22/09/12, 'Merkel, Hollande Mark Crucial de Gaulle Speech', France24, http://www.france24.com/en/20120922-france-germany-celebrate-50-years-friendship-charles-de-gaulle-ludwigshafen-free.

Scharpf, F W 1999, Governing in Europe: Effective and Democratic?, Oxford University Press, Oxford.

Schimmelfennig, F 1996, 'Legitimate Rule in the European Union', Tübinger Arbeitspapiere zur Internationalen Politik und Friedensforschung, Tübingen University, Tübingen.

Spiegel Staff 22/10/12, 'Is the Franco-German Axis Kaput?', Spiegel Online, http://www.spiegel.de/international/europe/crisis-of-confidence-develops-between-merkel-and-hollande-a-862644.html.

Traynor, I 19/10/12, 'EU Summit Leaves Controversial Issues Untouched', The Guardian, http://www.guardian.co.uk/business/2012/ oct/19/eu-summit-unresolved-issues.

Traynor, I 06/05/12, 'Francois Hollande's Chemistry with Merkel Crucial for Europe', The Guardian, http://www.guardian.co.uk/ world/2012/may/06/francois-hollande-angela-merkel-europe.

Velón, N 06/07/12, 'Europe's Banking Union: Possible Next Steps on a Bumby Path', Vox, http://www.voxeu.org/article/europe-s-bankingunion-possible-next-steps-bumpy-path.

Volkery, C 19/10/12, 'Berlin and Paris Compromise over Banking Oversight', Spiegel Online, http://www.spiegel.de/international/ europe/merkel-and-hollande-reach-summit-agreement-on-banking-oversight-a-862178.html.

Volkery, C 18/10/12, 'France and Germany at Odds Ahead of EU Summit', Spiegel Online, http://www.spiegel.de/international/europe/ france-and-germany-struggle-to-find-common-ground-ahead-ofeu-summit-a-862009.html. 